\title{
Example Ordinance for Compost Amending Soil in Urban Landscaping ${ }^{1}$
}

\author{
Jovana Radovanovic, James D. McGuire, Jana Caracciolo, Tom Ankersen, and Eban Z. Bean²
}

\section{Introduction}

Urban landscapes are commonly installed on a final grade consisting of fill material brought on-site during construction to elevate the land surface. This material is typically inert, lacking organic matter and nutrients, and becomes compacted during the construction process. UF/IFAS research and other studies (Radovanovic 2020; Bhadha et al. 2017; Zemanek 2014) have shown that incorporating compost into these soil conditions can increase water retention in the root zone and decrease the need for supplemental irrigation for turfgrass. As a result of this benefit, local governments may consider requiring amending of new landscapes. This publication describes an example ordinance that can be used by local governments as a starting point for developing a compost amendment ordinance tailored to their local situation and conditions. The example ordinance is divided into five sections. Section 1, Basis of Ordinance, provides the background information that supports the ordinance, while Section 2, Applicability, defines the situations and circumstances for which the ordinance shall be applied. Section 3, CompostAmended Soil Requirements, specifies the procedure for amending soils with compost, while Section 4, Compliance and Enforcement Procedures, covers how compliance shall be assessed and how the ordinance is enforced. Section 5, Other Clauses, includes any information that does not fall under the other sections along with the effective date. The content within each of these sections should be evaluated and adapted to the local context, rather than using material "as-is."

\section{Example Ordinance}

This document presents the various parts of an example ordinance developed for compost amending the soil in urban landscaping. The example ordinance was developed by collaborating faculty from the UF/IFAS Department of Agricultural and Biological Engineering and the UF Levin College of Law, and students from the UF Conservation Clinic. The example ordinance is intended for local governments interested in implementing such an ordinance. It is up to local governments to determine whether such an ordinance is appropriate for their circumstances, and if so, to adapt the sections to their unique circumstances. This document guides the reader through the example ordinance and suggests ways the ordinance can be adapted. The example ordinance document is included at the end of this publication.

Ordinances are enforceable by law and can be implemented by a city or county government. Ordinances may address a variety of issues, from local government structure to speed limits. The example ordinance was written in such a way that local governments could adapt it to their local circumstances. Underlined spaces or blanks indicate where

1. This document is AE566, one of a series of the Department of Agricultural and Biological Engineering, UF/IFAS Extension. Original publication date October 2021. Visit the EDIS website at https://edis.ifas.ufl.edu for the currently supported version of this publication.

2. Jovana Radovanovic, graduate student, Department of Agricultural and Biological Engineering; James D. McGuire, former student, UF Levin College of Law; Jana Caracciolo, former student, UF Levin College of Law; Tom Ankersen, professor, legal skills, and director, Conservation Clinic, UF Levin College of Law; and Eban Z. Bean, assistant professor, Department of Agricultural and Biological Engineering; UF/IFAS Extension, Gainesville, FL 32611.

The Institute of Food and Agricultural Sciences (IFAS) is an Equal Opportunity Institution authorized to provide research, educational information and other services

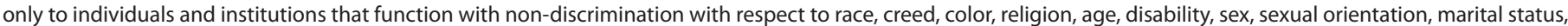

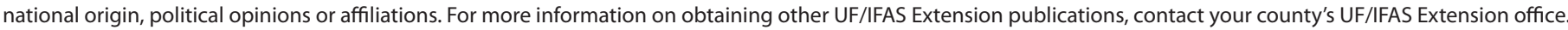
U.S. Department of Agriculture, UF/IFAS Extension Service, University of Florida, IFAS, Florida A \& M University Cooperative Extension Program, and Boards of County Commissioners Cooperating. Nick T. Place, dean for UF/IFAS Extension. 
information should be added to the document before it is considered for adoption. Brief guidance comments, which should be removed once the ordinance text is finalized, have been added to include relevant considerations for specific sections that local governments may want to adapt. The example ordinance is also intended to amend the local Land Development Code and is structured with this intent.

\section{Basis of Ordinance}

Section 1, the basis of ordinance, introduces the example ordinance scope through four subsections by establishing the justification and need for the ordinance. The items included in Finding of Fact (1.1), "whereas" statements, should be relevant to the local government in which it would be applied. Several of these statements have a scientific basis and generally apply to most local governments. However, additional relevant statements may be included, or irrelevant statements may be removed to justify the local context more appropriately. The ordinance title is established in Section 1.2 and sets how the ordinance will be referred to in other documents.

Subsection 1.3 covers the purpose and objectives of this ordinance. The purpose is to adopt compost-amended soil requirements and, by doing so, improve the function and health of soils post-construction. By adopting this ordinance, water conservation is promoted, runoff is reduced, and ecosystem services are enhanced. The objectives of the ordinance are to decrease the amount of irrigation needed in urban landscapes and reduce potential nutrient loads to water resources. It is also designed to promote environmental education and Extension opportunities on the benefits of amending soils. Again, the elements included here may be added to, removed, or modified for the local government context.

Subsection 1.4 clearly defines any vocabulary used in the ordinance. All terms included in this section should appear in the ordinance document. Additional terms may be added to reflect additional terminology incorporated elsewhere in the ordinance or to further clarify terminology in the existing document. Notably, within these definitions, "irrigable area" or "new construction" definitions may be modified to best fit the local government context.

\section{Applicability}

Section 2 sets the circumstances in which the ordinance applies. As written, the example ordinance would only apply to irrigable areas in landscapes of new construction that are 4,000 square feet or greater. Some local governments may choose to apply this more broadly by including "or replacement landscaping" or note specific zoning or other land use categories where this ordinance should apply. The area threshold may also be adjusted to apply to larger or smaller site disturbances. It may be advantageous for this threshold to align with similar spatial thresholds in other codes or ordinances.

\section{Compost-Amended Soil Requirements}

Section 3 establishes the compost application rate, incorporation depth, and type or quality. Soils in Florida can vary widely, and the incorporation of compost can have differing effects based on the soil texture. Incorporating compost into coarse sands can improve water retention, while incorporation into clay soils can improve infiltration. The soil conditions and local development practices should be considered when determining whether such an ordinance is appropriate. Furthermore, the ordinance does not cover other issues, such as standing water in landscapes, which may be the result of improper construction, grading, or over-irrigation, which are outside the scope of this ordinance. Bean et al. (2020) discuss more detailed background and installation steps.

The criteria included in the example ordinance are based on current UF/IFAS recommendations for landscapes as of publication of this document. Compost should be incorporated into the soil at a depth of at least 4 inches and an average of 6 inches. The stated application rate is 4 cubic yards per 1,000 square feet, but it may be reduced. The most recent UF/IFAS recommendations should be consulted or incorporated by reference (Bean et al. 2020). The example ordinance also gives specs for compost, stating the appropriate $\mathrm{pH}$ range and the nitrogen and phosphorus percentages. This section on amendment specifications may be altered based on scientific research or expert recommendations specific to the local context. An expert in this context may be defined as a soil scientist, engineer, or professional in a related field as determined by the local government.

Because compost contains nutrients that are especially available after initial incorporation (Radovanovic 2020), local governments may consider establishing an exclusion area not to be amended within a certain distance of surface water bodies (e.g., $25 \mathrm{ft}$ ), or other measure, due to the potential for initial nutrient release that could enter adjacent waters. 


\section{Compliance and Enforcement Procedures}

Section 4 describes how compliance with and enforcement of the ordinance will be accomplished through four subsections, including a description of the enforcing officer (4.1), public education of the ordinance and practice (4.2), circumstances for issuance of a notice of violation (4.3), and establishment of any penalties (4.4). The ordinance establishes the title of an enforcing officer, which can be a new position or a title applied to an existing staff position.

The enforcing officer (4.1) must have the necessary training to successfully inspect new construction within their jurisdiction to determine the extent of compliance. Ideally, any enforcement actions would be incorporated with the construction approval process. The enforcing officer may request soil samples or other measures to verify compliance. However, the enforcing officer must be granted permission from the owner before entering a site without a warrant. Therefore, local governments may consider developing or integrating this within an incentive program rather than being purely enforcement-oriented.

Public education (4.2) is included because it plays an important part in notifying local professionals and homeowners about the ordinance and can help to facilitate long-term resources conservation when properties are sold. Again, this should be integrated within any existing educational programs as closely as possible and can be explicitly stated here if necessary.

Subsection 4.3 lays out the procedure should any violations be found, and allows time for corrective action. If the responsible party neglects or refuses to take corrective action within the allotted time, the resulting penalties are included in Subsection 4.4. It is recommended that penalties correspond to local government requirements.

\section{Other Clauses}

Section 5 includes ancillary clauses that address the way the ordinance relates to conflicting ordinances, its severability, and the effective date of the ordinance. In Subsection 5.1, should any other ordinance come into conflict, this ordinance governs. If any part of this ordinance is invalidated, Subsection 5.2 allows the local government to address the invalidated portion, rather than invalidating the entire ordinance. Finally, Subsection 5.3 establishes the date that the ordinance becomes effective.

\section{Summary}

Conventional development practices result in frequent landscaping installation in compacted fill material that offers limited water retention and nutrients to vegetation. Amending with compost has been shown to improve the quality of soils and reduce the need for supplemental irrigation. As a result, local governments may consider creating an ordinance to require this practice. An example ordinance was developed to assist these local governments with this effort.

\section{References}

Bean, E., L. Jarrett, B. Haldeman, J. Kipp Searcy, and P. Jones. 2020. "Guidance for Amending Urban Soils with Organic Amendments." Florida Department of Environmental Protection. http://publicfiles.dep.state.fl.us/DEAR/ DEARweb/BMAP/BMP_Efficiencies/Guidance\%20for\%20 Amending\%20Urban\%20Soils\%20with\%20Organic\%20 Amendments_Final_20201012\%20(003).pdf

Bhadha, J. H., J. M. Capasso, R. Khatiwada, S. Swanson, and C. LaBorde. 2017. Raising Soil Organic Matter Content to Improve Water Holding Capacity. SL447. Gainesville: University of Florida Institute of Food and Agricultural Sciences. https://edis.ifas.ufl.edu/ss661

Bruun, E. W., C. T. Petersen, E. Hansen, J. K. Holm, and H. Hauggaard-Nielsen. 2014. "Biochar Amendment to Coarse Sandy Subsoil Improves Root Growth and Increases Water Retention." Soil Use and Management 30(1): 109-118. https://doi.org/10.1111/SUM.12102

Radovanovic, J. 2020. "Water Quality and Quantity Impacts of Amending New Residential Lawns with Compost in Florida." M.S. thesis. University of Florida. https://ufl-flvc.primo. exlibrisgroup.com/permalink/01FALSC_UFL/175ga98/ alma990381320910306597

Shaddox, T. W. 2017. General Recommendations for Fertilization of Turfgrasses on Florida Soils. SL21. Gainesville: University of Florida Institute of Food and Agricultural Sciences. https://edis.ifas.ufl.edu/lh014

U.S. Composting Council. n.d. Increasing Soil Organic Matter with Compost. Accessed August 25, 2021. https:// cdn.ymaws.com/www.compostingcouncil.org/resource/ resmgr/documents/compost_use/Increasing-the-OM-inSoil-7-.pdf 
Zemánek, P. 2014. "Evaluation of Compost Influence on Soil Water Retention." Acta Universitatis Agriculturae et Silviculturae Mendelianae Brunensis 59.3(2014): 227-232. https://doi.org/10.11118/actaun201159030227 
[City/County] of Florida

Chapter

Example Ordinance for Compost Amending Soil in Urban Landscaping

\section{Table of Contents}

SECTION _ _-1._BASIS OF ORDINANCE

Sec. -1.1.-Findings of Fact

Sec. -1.2.-Title of Ordinance

Sec. -1.3.-Ordinance Purpose and Objectives

Sec. -1.4.-Definitions

SECTION _ _-2._Applicability

SECTION _ _-3._Compost-Amended Soil Requirements

SECTION _-4._COMPLIANCE AND ENFORCEMENT PROCEDURES

Sec. _- 4.1._Enforcing Officer

Sec. _- 4.2._Public Education

Sec. _- 4.3._-Notice of Violation

Sec. -4.4.-Penalties

SECTION _ _ 5._OTHER CLAUSES

Sec. -5.1.-Conflict with Other Ordinances

Sec. -5.2.-Severability

Sec. -5.3.-Effective Date

ORDINANCE NUMBER 20_-_-

LAND DEVELOPMENT CODE

AN ORDINANCE OF THE [CITY/COUNTY] OF AMENDING [CITY/COUNTY] CODE CHAPTER PROVIDING FOR AMENDMENTS TO ADOPT COMPOST-AMENDED SOIL REQUIREMENTS; PROVIDING FOR REPEAL OF ORDINANCES; PROVIDING FOR TERRITORY EMBRACED; PROVIDING FOR SEVERABILITY; PROVIDING FOR INCLUSION INTO THE CODE OF ORDINANCES; PROVIDING FOR EFFECTIVE DATE. 
Sec. -1.1.-Findings of Fact

${ }^{*}$ Whereas, the [City/County] of recognizes that conventional construction and development practices commonly leave soils compacted, impeding root growth, reducing infiltration, and increasing runoff;

${ }^{\star}$ Whereas, the [City/County] of recognizes that soil at the land surface following completion of construction is relatively inert, low in organic matter, water holding capacity, and nutrient retention, relative to pre-existing topsoil;

${ }^{*}$ Whereas, the [City/County] of recognizes that poor soil quality inhibits establishment of resilient landscape vegetation, increasing reliance on supplemental irrigation, fertilizers, and pesticides;

*Whereas, the [City/County] of recognizes that the use of compost to amend soils has the purpose of enhancing the viability of new urban landscaping and reducing irrigation and fertilizer use;

${ }^{*}$ Whereas, the [City/County] of recognizes that improving soil quality in landscaped areas for all new construction improves the conservation of water resources;

${ }^{*}$ Whereas, the [City/County] of recognizes that the important public health, safety, and welfare objective of conserving valuable resources including water and soil will be served and advanced by the enactment of compostamended soils requirements;

*Whereas, the [City/County] of recognizes that by 2035 the State of Florida is expected to face a 400 million gallon per day deficit in supply to meet demand; and

${ }^{\star}$ Whereas, the [City/County] of recognizes that both its economy and the quality of life of its residents are enriched by a sustainable environment; and

${ }^{\star}$ Whereas, the [City/County] of desires to minimize the detrimental impact on water resources that comes from over pumping water and runoff from over reliance on irrigation and nutrient exports from the improper use of fertilizers.

Guidance: These generic Findings of Fact are illustrative only. Some Findings of Fact should also relate to the specific context of the County or City adopting a compost-amended soil Ordinance and may include data on the use of soil that has not been amended with compost as it compares to compost-amended soil.

NOW, THEREFORE, BE IT ORDAINED, BY THE [CITY COUNCIL/BOARD OF COUNTY] COMMISSIONERS OF THE [CITY/COUNTY] OF ON THIS DAY OF 20

Sec. -1.2. - Title of Ordinance

The [City/County] of Ordinance for Compost Amending Soil in Urban Landscaping is hereby established.

Guidance: The City or County is free to and should tailor the name of the Ordinance in its own code accordingly.

\section{Sec.} -1.3.-Ordinance Purpose and Objectives

The purpose of this Ordinance is to improve the function and health of soils post-construction, to promote water conservation by reducing landscape irrigation, and to protect water quality by improving soil health, reducing runoff, enhancing ecosystem services, and retaining nutrients in soils in urban landscaping in the [City/County] of 
The objective of the Ordinance is to decrease the amount of irrigation needed for urban landscaping and reduce potential contributions of fertilizer to pollution by ensuring that new urban landscaping projects require the use of soil that has been amended with compost. In furtherance of this objective, this Ordinance is also designed to promote environmental education and extension for residents in the [City/County] of on the benefits of amending soils.

Sec. -1.4.-Definitions

Compost-amended soil: Compost-amended soil has the meaning set forth in Section -3 of this Ordinance.

Irrigable area: Any area where soil is disturbed in order to install landscaping associated with new construction, and could be irrigated using the typical equipment, means, and quantity of water available to any resident or commercial entity of [City/County].

Guidance: Jurisdictions may expand or limit the scope of an irrigable area as they see fit.

Landscape: The public or private areas of land to be modified with vegetation and ground covers in order to create visual features and aesthetic such as: lawns, gardens, community common areas, and parks.

Landscaping: Modifying the visible features of an area of land, including seeding grass or laying sod; installing or planting flora and other visual elements; gardening; or the art and craft of growing plants with a goal of creating aesthetic.

New construction: Any structure for which the start date of construction begins on or after the effective date of this Ordinance. New construction includes any redevelopment or modification for which the start date of construction begins on or after the effective date of this Ordinance.

Guidance: Some local governments may wish to apply this Ordinance more broadly. Further, the definition for "new construction" should follow what the City or County's building code defines as new construction. If the City or County wishes to include this Ordinance in a building code, the definition of new construction should be in accordance with those permitting requirements.

Soil Preparation: Soil preparation has the meaning set forth in Section __ -3 of this Ordinance.

\section{SECTION__-2._Applicability}

The provisions of this Ordinance apply to all irrigable areas within landscapes of new construction within the [County/ City] of __ The provisions of this Ordinance apply to irrigable landscape areas of 4,000 square feet ( 0.092 acres) or greater.

Guidance: Some local governments may wish to apply this Ordinance more broadly to "new" or "replacement" landscaping and to identify specific zoning or other land use categories. The area of 4,000 square feet is used as an example of a reasonable area--local governments should feel free to increase or decrease the covered area in accordance with their individual needs.

\section{SECTION _ -3._Compost-Amended Soil Requirements}

Owners of the areas specified in Section __ 2 above shall perform soil preparation, which is to incorporate compost into the soil within landscapable areas of new construction projects to a depth of at least 4 inches and average of 6 inches at a rate of 4 cubic yards per 1,000 square feet, or whatever the current guidance from the University of Florida Institute of Food and Agricultural Sciences (UF/IFAS) provides, prior to installing landscaping material.

Guidance: Description and justification. Could be subject to the individual County or City's discretion.

Owners shall use compost certified by the US Composting Council where available. 
Where certified compost is not available, amended soil shall conform to the following descriptive criteria:

The amended soil shall have an organic matter content of greater than two (2) percent and a $\mathrm{pH}$ between 5.5 and 8.0, and shall be free from noxious weeds and roots, salts, clay lumps, any non-soil materials such as rock, concrete, brick chips, or building materials, foreign matter, and any chemical, biological, or radiological contaminants. The amendments shall have dry weight content equal to or less than $2.0 \%$ nitrogen and $0.8 \%$ phosphorus. The quality of amended soil should be in accordance with the current guidance provided by UF/IFAS.

Guidance: The local government may alter the amendment quality language based on scientific research or expert recommendations. Local governments may also choose to include specific alternative amendments such as, but not limited to, topsoil scraped and retained from grading, on-site muck soils, or on-site native peat.

\section{SECTION _ -4._COMPLIANCE AND ENFORCEMENT PROCEDURES}

\section{Sec. _- 4.1._Enforcing Officer}

A position, known as the [City/County] of____ Enforcing Officer, is hereby established.

Guidance: Local governments may choose to identify someone already on staff, such as a code enforcement officer or building inspector, for the position. Local governments may also choose to provide for a soil amendment provision in an existing building code or water use code. It is most important that the designated individual receive appropriate training.

The [City/County] Manager shall appoint the Enforcing Officer. The Enforcing Officer must have the necessary training and technical knowledge to enable them to effectively carry out the duties of this office.

The Enforcing Officer shall inspect all new construction within the jurisdictional boundaries of the [City/County] of prior to occupancy, in order to determine the extent of compliance with this Ordinance. The Enforcing Officer may request soil samples, construction of an observation hole, or other measures to verify compliance.

Guidance: In some jurisdictions, the enforcing official may be able to undertake these activities as part of the construction approval process. The Enforcing Officer may not enter a site to ensure compliance without the owner's consent, an administrative search warrant, or an inspection warrant issued pursuant to the Florida Statutes. Thus, it would be practical to tie the enforcement of this ordinance to an existing permitting process or an incentive program created by the municipality.

It shall be unlawful for any person to interfere with, or in any manner hinder, the Enforcing Officer, or any of the Enforcing Officer's assistants, while in the discharge of their duties under the terms of this Ordinance.

Sec. -4.2.-Public Education

The [City/County] shall coordinate public education and extension with or through new or existing programs for landscaping or builder professionals and homeowners. Information shall be provided to new homeowners about their compostamended soil and facilitate the continuation of water and nutrient conservation when existing homes are sold.

Sec. -4.3.- Notice of Violation

Upon finding any violation of this Ordinance, the Enforcing Officer shall deliver a written notice of the violation of this Ordinance to the property owner. The notice shall direct the property owner to promptly address soil preparation not in compliance with this Ordinance.

The notice shall state the time allowed for properly amending the soil. Should the responsible party neglect or refuse to address the violation within the time stated in the notice, the responsible party shall be penalized as provided in Subsection -4.4 of this Ordinance. 

-4.4.-Penalties

Any person who violates any portion of this Ordinance without an exception or variance granted by [City/County] commits a civil infraction and is subject to the penalty provisions of [City/County] Code.

Guidance: Penalties should be in accordance with this City or County's local requirements.

\section{SECTION _ -5._OTHER CLAUSES}

\section{Sec. _-5.1._Conflict with Other Ordinances}

If this Ordinance conflicts with any other Ordinance or requirement of the [City/County] of then the provisions of this Ordinance govern. Deviations from this Ordinance for the health, safety, and welfare are subject to the variance procedures as established by this [City/County].

Sec. -5.2.-Severability

If any Section or Subsection of this Ordinance is invalidated for any reason, [City/County] may eliminate or modify the invalidated portion in order to correct it. [City/County] shall not eliminate or modify the invalidated portion if doing so will materially alter or negate the Ordinance Goals.

Sec. -5.3.-Effective Date

The [City/County] of Ordinance for Amending Soil in Urban Landscaping becomes effective upon recommendation by and approval by the

This Ordinance is effective in [City/County] as of [mm/dd/yyyy].

${ }^{1}$ See Eban Z. Bean, et al., Effect of urban soil compaction on infiltration rate, 61.3J. Soil \& Water Conservation at 117-124 (2006), https://www.jswconline.org/content/61/3/117; see also Eban Z. Bean \& Michael D. Dukes, Effect of amendment type and incorporation depth on runoff from compacted sandy soils, 141.6 Am. Soc'y Civ. Engineers J. (2015), https://ascelibrary. org/doi/abs/10.1061/\%28ASCE\%29IR.1943-4774.0000840.

${ }^{2}$ See Craig G. Cogger, Potential compost benefits for restoration of soils disturbed by urban development, 13.4 J. Compost Sci. \& Utilization at 243-51 (2005), https://www.tandfonline.com/doi/abs/10.1080/1065657X.2005.10702248; see also Bryant C. Scharenbroch, et al., Distinguishing urban soils with physical, chemical, and biological properties, 49.4 Pedobiologia at 283-96 (2005), https://www.sciencedirect.com/science/article/pii/S0031405605000077.

${ }^{3}$ See Bean \& Dukes, supra note 1; see also Cogger, supra note 2.

${ }^{4}$ See Melissa B. Haley, et al., Residential irrigation water use in central Florida, 133.5 J. Irrigation \& Drainage Engineering at 427-34.

${ }^{5}$ Office of Econ. \& Demographic Res., Ann. Assessment of Fla. Water Resources \& Conservation Lands at 120, tbl. 3.2.2 (2018), http://edr.state.fl.us/Content/natural-resources/LandandWaterAnnualAssessment_2018Edition.pdf.

${ }^{6}$ Defined terms should closely follow those created by UF/IFAS in the Model Florida-Friendly Landscaping ${ }^{\mathrm{TM}}$ Contract (2018), https://ffl.ifas.ufl.edu/materials/Florida_Friendly_Landscaping_Maintenance_Contract_2018.pdf.

${ }^{7}$ See, e.g., Model Florida-Friendly Landscaping ${ }^{\mathrm{TM}}$ Contract (2018), https://ffl.ifas.ufl.edu/materials/Florida_Friendly_Landscaping_Maintenance_Contract_2018.pdf (defining "irrigated landscape area" as any outdoor area that has a permanent irrigation system). 
${ }^{8}$ See Re: Local Gov't Code Enforcement Boards Act-Entry on certain premises by local code inspector without consent or inspection or search warrant authorized, 84-32 Op. Fla. Att'y Gen. (Apr. 2, 1984) http://www.myfloridalegal.com/ago.nsf/ Opinions/486093F9C929D04A85256583006C8F9C (last visited Nov. 9, 2020); see also Code Publishing.com, Bainbridge Island Wash. Municipal Code $\$ 1.16$, https://www.codepublishing.com/WA/BainbridgeIsland/html/BainbridgeIsland01/ BainbridgeIsland0116.html\#: :text=If\%20the\%20building\%20or\%20property,the\%20inspection\%2C\%20and\%20 request\%20entry (last visited Nov. 9, 2020) (providing further guidance on obtaining entry to private property for inspection). 